\title{
NICKEL OXIDE IN GLAZES'
}

By J. D. WhITMER

\section{ABSTRACT}

Colors produced from NiO.- -The literature on this subject published in the Transactions of the Society is briefly reviewed.

Effects of variations of RO in cone 6 glazes on colors from nickel oxide.Red colors are produced when $\mathrm{ZnO}$ and $\mathrm{BaO}$ are used in certain proportions. Blues and purples of varied shades and hues are developed with varied combinations of $\mathrm{ZnO}, \mathrm{CaO}$ and $\mathrm{BaO}$. Grays are possible in presence of. $\mathrm{CaO}$ and MgO.

The transactions of our Society contain a few references to the colors produced by nickel oxide in glazes. These references are scattered through a number of volumes. To gather up the data and present it together with any new developments which might be obtained is the purpose of this paper. Furthermore, it was desired to determine, if possible, the influence exerted by each $\mathrm{RO}$ oxide on colors produced by oxide of nickel.

The conditions outlined make necessary, therefore, some overlapping with work previously done. This repetition, however, serves a useful purpose in emphasizing and strengthening conclusions already drawn.

Geijsbeck $^{2}$ states that I,e Chatielier and Chaupuy in Paris reported the following colors obtained from nickel oxide in oxidizing fire: violet, blue, green, yellow, red and brown. Many of these colors are familiar to most of us. Some no doubt are unusual. Browns and yellows are the usual colors in lead glazes and under ordinary conditions. Blues and greens, more or less familiar colors, were once attributed to traces of cobalt in with the oxide of nickel.

Pence, however, in his study, "Colors Produced by Nickel Oxide in Ceramic Mixtures Containing Zinc," demonstrates that nickel oxide of the highest purity gives colors changing from

I Received March 10, 1921.

2 Trans. A. C. S., 6, 195.

${ }^{3}$ Trans. A. C. S., 14, p. 144. 
brown through purple, reddish purple to blue as $\mathrm{ZnO}$ replaces $\mathrm{BaO}$ and $\mathrm{CaO}$, and further that the blues thus obtained can not be duplicated by the use of cobalt oxide.

Nothing more red than the reddish tone of purple obtained by Pence had ever come under my observation. Hence the possibility of producing a red color from $\mathrm{NiO}$ was quite alluring. In paper presented ${ }^{1}$ last year it was demonstrated that gray colors are produced by $\mathrm{NiO}$ in the presence of $\mathrm{MgO}$.

\section{Experimental}

Inasmuch as this work is a continuation and enlargement of that previously reported, the base glaze used was the same and much of the present investigation was based on the results obtained at that time. The work was so planned that as each RO oxide replaced another the effect on the color produced by $\mathrm{NiO}$ could be noted.

The following base glaze was used:

$$
\left.\begin{array}{r}
0.25 \mathrm{~K}_{2} \mathrm{O} \\
.45 \mathrm{BaO} \\
.30 \mathrm{CaO}
\end{array}\right\} 0.35 \mathrm{Al}_{2} \mathrm{O}_{3}-2.00 \mathrm{SiO}_{2}
$$

The amount of $\mathrm{NiO}$ used was kept at 0.025 equivalent except in Series X; it was a straight addition to each glaze.

Series $1-\mathrm{ZnO}$ vs. $\mathrm{BaO}$. - This is a continuation of a series in the previous paper ${ }^{2}$ in which $\mathrm{ZnO}$ replaces $\mathrm{BaO}$. In the present instance the $\mathrm{ZnO}$ replaces $\mathrm{BaO}$ by 0.05 equivalent until the latter is eliminated from the formula.

Series $2-\mathrm{CaO}$ vs. $\mathrm{K}_{2} \mathrm{O}$. - With no $\mathrm{BaO}$ in the $\mathrm{RO}, \mathrm{CaO}$ replaces $\mathrm{K}_{2} \mathrm{O}$ by 0.05 equivalent until the latter is eliminated from the formula. It will be noted here that the final $0.05 \mathrm{~K}_{2} \mathrm{O}$ was replaced by $0.05 \mathrm{ZnO}$ making the last glaze of the series have an $\mathrm{RO}$ of $0.5 \mathrm{ZnO}, 0.5 \mathrm{CaO}$.

Series $3-\mathrm{ZnO}$ vs. $\mathrm{CaO}$.-We start this series with the original $\mathrm{RO}$ formula, $0.25 \mathrm{~K}_{2} \mathrm{O}, 0.30 \mathrm{CaO}, 0.45 \mathrm{BaO}$. $\mathrm{ZnO}$ replaces $\mathrm{CaO}$ by 0.05 equivalent until $\mathrm{CaO}$ is eliminated from the formula. We may compare this with Series 1 wherein $\mathrm{ZnO}$ replaces $\mathrm{BaO}$.

1 J. Am. Ceram. Soc., 1920, 663.

${ }^{2}$ Loc. cit. 
Series $4-\mathrm{ZnO}$ vs. $\mathrm{K}_{2} \mathrm{O}$.-Wishing to parallel the high $\mathrm{CaO}-$ $\mathrm{ZnO}$ glaze of Series 2 , the $\mathrm{K}_{2} \mathrm{O}$ in glaze 6 of Series 3 was replaced by $\mathrm{ZnO}$ in increments of 0.05 equivalent until the content of $0.5 \mathrm{ZnO}$ is reached. The remaining $0.05 \mathrm{~K}_{2} \mathrm{O}$ is then replaced by $0.05 \mathrm{BaO}$ and we have glaze 5 with an $\mathrm{RO}$ content of 0.5 $\mathrm{BaO}, 0.5 \mathrm{ZnO}$.

In order to determine the different effects produced when $\mathrm{MgO}$ replaced each of the other $\mathrm{RO}$ oxides, the four following series were constructed:

Series 5.-With an RO consisting of $0.15 \mathrm{~K}_{2} \mathrm{O}, 0.40 \mathrm{ZnO}$, $0.45 \mathrm{BaO}$ as in glaze 2 , series $4, \mathrm{MgO}$ replaces $\mathrm{BaO}$ by 0.05 equivalents up to and including $0.20 \mathrm{MgO} . \quad \mathrm{ZnO}$ and $\mathrm{K}_{2} \mathrm{O}$ do not change.

Series 6.-With the same $\mathrm{RO}$ as in Series 5, $\mathrm{MgO}$ replaces $\mathrm{ZnO}$ in like manner, the $\mathrm{BaO}$ and $\mathrm{K}_{2} \mathrm{O}$ remaining unchanged.

Series 7.-Starting with an RO consisting of $0.15 \quad \mathrm{~K}_{2} \mathrm{O}$, $0.45 \mathrm{CaO}, 0.40 \mathrm{ZnO}, \mathrm{MgO}$ replaces $\mathrm{CaO}$ by 0.05 equivalents until a content of $0.20 \mathrm{MgO}$ is reached. $\mathrm{ZnO}$ and $\mathrm{K}_{2} \mathrm{O}$ remain unchanged.

Series 8.-Using the same $\mathrm{RO}$ as in series $7, \mathrm{MgO}$ replaces $\mathrm{ZnO}$ in like manner, the $\mathrm{K}_{2} \mathrm{O}$ and $\mathrm{CaO}$ remaining constant.

When the results of these eight series were noted and it was found that a red color was obtained in glaze 2 , series 4 , the two following series were added to indicate what effect, if any, variations in the $\mathrm{Al}_{2} \mathrm{O}_{3}$ and $\mathrm{NiO}$ content might have on the red color.

Series 9.-Starting with glaze 2 , series $4, \mathrm{Al}_{2} \mathrm{O}_{3}$ was reduced by 0.05 equivalents to 0.10 equivalent, keeping the oxygen ratio constant at $1: 2$.

Series 10.-With the same glaze, the nickel oxide was varied from 0.025 to 0.10 equivalent.

Materials.-Formulae and batch weights of all the glazes are found in table 1 . The materials used in this investigation were taken from regular factory stock and include the following: Eureka Feldspar, English Cliffstone Whiting, Red Seal Oxide of Zinc, Oxide of Nickel, Granville Flint, Cornwall Stone, Precipitated Barium Carbonate, Calcined Magnesite, Calcined N. C. Kaolin. 
TABLE 1

Series 1

Common to all glazes: $0.35 \mathrm{Al}_{2} \mathrm{O}_{3} ; 2.00 \mathrm{SiO}_{2} ; 0.025 \mathrm{NiO}$

Formulae

$\begin{array}{ccccc}\text { Giaze } & & & & \\ \text { No. } & \mathrm{K}_{2} \mathrm{O} & \mathrm{CaO} & \mathrm{BaO} & \mathrm{ZnO} \\ 1 & 0.25 & 0.30 & 0.20 & 0.25 \\ 2 & .25 & .30 & .15 & .30 \\ 3 & .25 & .30 & .10 & .35 \\ 4 & .25 & .30 & .05 & .40 \\ 5 & .25 & .30 & .00 & .45\end{array}$

Batch Weights

\begin{tabular}{|c|c|c|c|c|c|c|}
\hline $\begin{array}{l}\text { Feld- } \\
\text { spar }\end{array}$ & Stone & $\begin{array}{l}\text { Whit- } \\
\text { ing }\end{array}$ & $\begin{array}{l}\text { Barium } \\
\text { Carb. }\end{array}$ & $\begin{array}{l}\text { Oxide } \\
\text { Zinc }\end{array}$ & $\begin{array}{l}\text { Calc. } \\
\text { Clay }\end{array}$ & $\begin{array}{l}\text { Nickel } \\
\text { Flint Oxide }\end{array}$ \\
\hline 33.4 & 84.3 & 30.0 & 39.4 & 20.25 & 14.43 & 1.87 \\
\hline 4 & 84 & 30 & 29 & & & 1.87 \\
\hline & 84. & 30 & 19 & 28 & 14 & 1.87 \\
\hline 1. & 84.3 & 30.0 & 9.85 & 32.40 & 14.43 & 1.87 \\
\hline .4 & 84.3 & 30.0 & & 36.45 & 14.43 & 1.87 \\
\hline
\end{tabular}

Series 2

Common to all glazes: $0.35 \mathrm{Al}_{2} \mathrm{O}_{3} ; 2.00 \mathrm{SiO}_{2} ; 0.025 \mathrm{NiO}$

\begin{tabular}{rrrrrrrrrrrrr}
1 & 0.20 & 0.35 & $\ldots$ & 0.45 & 83.4 & 42.15 & 35.0 & $\ldots$ & 36.45 & 29.41 & 19.74 & 1.87 \\
2 & .15 & .40 & $\ldots$ & .45 & 55.6 & 42.15 & 40.0 & $\ldots$ & 36.45 & 40.51 & 31.74 & 1.87 \\
3 & .10 & .45 & $\ldots$ & .45 & 55.6 & $\ldots$ & 45.0 & $\ldots$ & 36.45 & 55.50 & 54.00 & 1.87 \\
4 & .05 & .50 & $\ldots$ & .45 & 27.8 & $\ldots$ & 50.0 & $\ldots$ & 36.45 & 66.60 & 66.00 & 1.87 \\
5 & .00 & .50 & $\ldots$ & .50 & $\ldots$ & $\ldots$ & 50.0 & $\ldots$ & 40.50 & 77.70 & 78.00 & 1.87 \\
& & & \multicolumn{5}{c}{ Series 3} & & & & &
\end{tabular}

Common to all glazes: $0.35 \mathrm{Al}_{2} \mathrm{O}_{3} ; 2.00 \mathrm{SiO}_{2} ; 0.025 \mathrm{NiO}$

$\begin{array}{rrrrrrrrrrrrr}1 & 0.25 & 0.25 & 0.45 & 0.05 & 83.4 & 84.3 & 25.0 & 88.65 & 4.05 & 14.43 & \ldots & 1.87 \\ 2 & .25 & .20 & .45 & .10 & 83.4 & 84.3 & 20.0 & 88.65 & 8.10 & 14.43 & \ldots & 1.87 \\ 3 & .25 & .15 & .45 & .15 & 83.4 & 84.3 & 15.0 & 88.65 & 12.15 & 14.43 & \ldots & 1.87 \\ 4 & .25 & .10 & .45 & .20 & 83.4 & 84.3 & 10.0 & 88.65 & 16.20 & 14.43 & \ldots & 1.87 \\ 5 & .25 & .05 & .45 & .25 & 83.4 & 84.3 & 5.0 & 88.65 & 20.25 & 14.43 & \ldots & 1.87 \\ 6 & .25 & .00 & .45 & .30 & 83.4 & 84.3 & \ldots & 88.65 & 24.30 & 14.43 & \ldots & 1.87\end{array}$

Series 4

Common to all glazes: $0.35 \mathrm{Al}_{2} \mathrm{O}_{3} ; 2.00 \mathrm{SiO}_{2} ; 0.025 \mathrm{NiO}$

$\begin{array}{rrrrrrrrrrrrr}1 & 0.20 & \ldots & 0.45 & 0.35 & 83.40 & 42.15 & \ldots & 88.65 & 28.35 & 29.41 & 19.74 & 1.87 \\ 2 & .15 & \ldots & .45 & .40 & 55.60 & 42.15 & \ldots & 88.65 & 32.40 & 40.51 & 31.74 & 1.87 \\ 3 & .10 & \ldots & .45 & .45 & 55.60 & \ldots & \ldots & 88.65 & 36.45 & 55.50 & 54.00 & 1.87 \\ 4 & .05 & \ldots & .45 & .50 & 27.80 & \ldots & \ldots & 88.65 & 40.50 & 66.60 & 66.00 & 1.87 \\ 5 & .00 & \ldots & .50 & .50 & \ldots & \ldots & \ldots & 98.50 & 40.50 & 77.70 & 78.00 & 1.87\end{array}$

Series 5

Common to all glazes: $0.35 \mathrm{Al}_{2} \mathrm{O}_{3} ; 2.00 \mathrm{SiO}_{2} ; 0.025 \mathrm{NiO}$

Formulae

\begin{tabular}{|c|c|c|c|c|c|c|c|c|c|c|}
\hline \multirow[b]{2}{*}{$\begin{array}{l}\text { Glaze } \\
\text { No. }\end{array}$} & \multicolumn{4}{|c|}{ Formulae } & \multicolumn{6}{|c|}{ Batch Weights } \\
\hline & $\mathrm{K}_{2} \mathrm{O}$ & $\mathrm{BaO}$ & $\mathrm{ZnO}$ & $\mathrm{MgO}$ & $\begin{array}{l}\text { Feld- } \\
\text { spa: }\end{array}$ & Stone & $\begin{array}{l}\text { Barium Oxide } \\
\text { Carb. Zine. }\end{array}$ & $\begin{array}{l}\text { Calc. } \\
\text { Mag- } \\
\text { nesite }\end{array}$ & $\begin{array}{l}\text { Caic. } \\
\text { Clay }\end{array}$ & Flint $\begin{array}{c}\text { Nickel } \\
\text { Oxide }\end{array}$ \\
\hline 1 & 0.15 & 0.45 & 0.40 & 0.00 & 55.60 & 42.15 & 88.6532 .40 & & 40.51 & $31.74 \quad 1.87$ \\
\hline 2 & .15 & .40 & .40 & .05 & 55.60 & 42.15 & 8032.40 & 2.015 & 40.51 & 31.74 \\
\hline 3 & .15 & .35 & .40 & .10 & 55 & 42.15 & 532.40 & 4.030 & 40 & $31.74 \quad 1.87$ \\
\hline 4 & .15 & .30 & .40 & .15 & 55.60 & 42.15 & $59.10 \quad 32.40$ & 6.045 & 40.51 & $31.74 \quad 1.87$ \\
\hline 5 & .15 & .25 & .40 & .20 & 55.60 & 42.15 & $49.25 \quad 32.40$ & 8.060 & 40.51 & $31.74 \quad 1.87$ \\
\hline
\end{tabular}


Series 6

Common to all glazes: $0.35 \mathrm{Al}_{2} \mathrm{O}_{3} ; 2.00 \mathrm{SiO}_{2} ; 0.025 \mathrm{NiO}$

$\begin{array}{rrrrrrrrrrrrr}1 & 0.15 & 0.45 & 0.35 & 0.05 & 55.60 & 42.15 & 88.65 & 28.35 & 2.015 & 40.51 & 31.74 & 1.87 \\ 2 & .15 & .45 & .30 & .10 & 55.60 & 42.15 & 88.65 & 24.30 & 4.030 & 40.51 & 31.74 & 1.87 \\ 3 & .15 & .45 & .25 & .15 & \mathbf{5 5 . 6 0} & 42.15 & 88.65 & 20.25 & 6.045 & 40.51 & 31.74 & 1.87 \\ 4 & .15 & .45 & .20 & .20 & \mathbf{5 5 . 6 0} & 42.15 & 88.65 & 16.20 & 8.060 & 40.51 & 31.74 & 1.87\end{array}$

Series 7

Common to all glazes: $0.35 \mathrm{Al}_{2} \mathrm{O}_{3} ; 2.00 \mathrm{SiO}_{2} ; 0.025 \mathrm{NiO}$

$\mathrm{CaO}$

$\begin{array}{llllll}1 & 0.15 & 0.40 & 0.45 & 0.00\end{array}$

$\begin{array}{llllll}2 & .15 & .35 & .45 & .05\end{array}$

$\begin{array}{llllll}3 & .15 & .30 & .45 & .10\end{array}$

$\begin{array}{lllll}4 & .15 & .25 & .45 & .15\end{array}$

$\begin{array}{lllll}5 & .15 & .20 & .45 & .20\end{array}$
Whiting

$\begin{array}{llllllll}55.6 & 42.15 & 40.0 & 36.45 & \ldots & 40.51 & 31.74 & 1.87\end{array}$

$\begin{array}{lllllllll}55.6 & 42.15 & 35.0 & 36.45 & 2.015 & 40.51 & 31.74 & 1.87\end{array}$

$\begin{array}{lllllllll}55.6 & 42.15 & 30.0 & 36.45 & 4.030 & 40.51 & 31.74 & 1.87\end{array}$

$\begin{array}{lllllllll}55.6 & 42.15 & 25.0 & 36.45 & 6.045 & 40.51 & 31.74 & 1.87\end{array}$

$\begin{array}{lllllllll}55.6 & 42.15 & 20.0 & 36.45 & 8.060 & 40.51 & 31.74 & 1.87\end{array}$

Series 8

Common to all glazes: $0.35 \mathrm{Al}_{2} \mathrm{O}_{3} ; 2.00 \mathrm{SiO}_{2} ; 0.025 \mathrm{NiO}$

$$
\mathrm{CaO}
$$

Whiting

$\begin{array}{rrrrrrr}1 & 0.15 & 0.40 & 0.40 & 0.05 & 55.6 \\ 2 & .15 & .40 & .35 & .10 & 55.6 \\ 3 & .15 & .40 & .30 & .15 & 55.6 & 42 \\ 4 & .15 & .40 & .25 & .20 & 55.6\end{array}$

$\begin{array}{lllllll}42.15 & 40.0 & 32.40 & 2.015 & 40.51 & 31.74 & 1.87\end{array}$

$\begin{array}{lllllll}42.15 & 40.0 & 28.35 & 4.030 & 40.51 & 31.74 & 1.87\end{array}$

$\begin{array}{llllllll}42.15 & 40.0 & 24.30 & 6.045 & 40.51 & 31.74 & 1.87\end{array}$

$\begin{array}{llllllll}42.15 & 40.0 & 20.25 & 8.06 & 40.51 & 31.74 & 1.87\end{array}$

Common to all glazes: $0.45 \mathrm{BaO} ; 0.025 \mathrm{NiO}$

\begin{tabular}{|c|c|c|c|c|c|c|c|c|}
\hline \multirow[b]{2}{*}{$\begin{array}{l}\text { Glaze } \\
\text { No. }\end{array}$} & \multicolumn{3}{|c|}{ Formulae } & \multicolumn{5}{|c|}{ Batch Weights } \\
\hline & $\mathrm{K}_{2} \mathrm{O}$ & $\mathrm{ZnO}$ & $\mathrm{Al}_{2} \mathrm{O}_{2} \mathrm{SiO}_{2}$ & $\begin{array}{l}\text { Feld- } \\
\text { spar }\end{array}$ & Stone & $\begin{array}{l}\text { Barium Oxide } \\
\text { Carb. Zine }\end{array}$ & $\begin{array}{l}\text { Calc. } \\
\text { Clay }\end{array}$ & $\begin{array}{r}\text { Nickel } \\
\text { Flint Oxide }\end{array}$ \\
\hline 1 & 0.15 & 0.40 & 0.352 .00 & 55.6 & 42.15 & 88.6532 .40 & 40.51 & $\begin{array}{lll}31.74 & 1.87\end{array}$ \\
\hline 2 & .15 & .40 & $.30 \quad 1.90$ & 55.6 & 42.15 & 88.6532 .40 & 29.41 & $31.74 \quad 1.87$ \\
\hline 3 & .15 & .40 & $.25 \quad 1.75$ & 55.6 & 42.15 & 88.6532 .40 & 18.32 & $28.74 \quad 1.87$ \\
\hline 4 & .15 & .40 & .201 .60 & 55.6 & 42.15 & 88.6532 .40 & 7.22 & $25.74 \quad 1.87$ \\
\hline 5 & .15 & 40 & .151 .45 & 83.4 & $\ldots$ & $\begin{array}{lll}88.65 & 32.40\end{array}$ & $\ldots$ & $\begin{array}{lll}33.00 & 1.87\end{array}$ \\
\hline 6 & 10 & .45 & .101 .30 & 55.6 & $\cdots$ & 88.6536 .45 & $\ldots$ & $\begin{array}{lll}42.00 & 1.87\end{array}$ \\
\hline
\end{tabular}

\begin{tabular}{|c|c|c|c|c|c|c|c|c|c|}
\hline \multirow[b]{2}{*}{$\begin{array}{c}\text { Glaze } \\
\text { No. }\end{array}$} & \multicolumn{3}{|c|}{ Formulae } & \multicolumn{6}{|c|}{ Batch Weights } \\
\hline & $\mathrm{K}_{2} \mathrm{O}$ & $\mathrm{ZnO} \mathrm{Al}_{2} \mathrm{O}_{3}$ & $\mathrm{NiO}$ & $\begin{array}{l}\text { Feld- } \\
\text { spar }\end{array}$ & Stone & $\begin{array}{l}\text { Barium Oxide } \\
\text { Carb. Zine }\end{array}$ & $\begin{array}{l}\text { Calc. } \\
\text { Clay }\end{array}$ & Flint & $\begin{array}{l}\text { Nickel } \\
\text { Oxide }\end{array}$ \\
\hline 1 & 0.15 & $\begin{array}{lll}0.40 & 0.35\end{array}$ & 0.025 & 55.6 & 42.15 & 88.6532 .4 & 40.51 & 31.74 & 1.87 \\
\hline 2 & .15 & $.40 \quad .35$ & .050 & 55.6 & 42.15 & 88.6532 .4 & 40.51 & 31.74 & 3.74 \\
\hline 3 & .15 & $.40 \quad .35$ & .075 & 55.6 & 42.15 & $88.65 \quad 32.4$ & 40.51 & 31.74 & 5.61 \\
\hline 4 & .15 & $.40 \quad .35$ & .100 & 55.6 & 42.15 & 88.6532 .4 & 40.51 & 31.74 & 7.48 \\
\hline
\end{tabular}


The glazes were weighed up separately, ground in small trial mills and applied, by dipping, to thin porous wall tile bisque $\left(1^{1} / 2^{\prime \prime} \times 11^{\prime \prime} \times 0^{1} / 8^{\prime \prime}\right)$.

All glazes except those of series 9 and 10 were fired at the same time in a commercial down-draft kiln. The fuel used was natural gas. Cones placed in each sagger of glazed tile indicated a temperature corresponding to cone 6 .

The majority of the glazes were matured at this temperature although some of those high in $\mathrm{MgO}$ were somewhat immature. The glazes of series 9 and 10 were fired at another time but the cones indicated a heat treatment very similar to that of the first burn.

\section{Results}

Series 1.-Glaze 1, reddish purple; glaze 2 , more blue than glaze 1 ; glaze 3 , mingled blue and tan, the blue apparently consisting of crystals on a tan background; glaze 4, goes bright, blue where thickest, yellowish color on edges of tile where thinnest; glaze 5, greenish matt, tending to blue crystalline where thickest.

The odd behavior of glaze 4 which went bright was attributed to a mistake in weighing the glaze, but a new batch, carefully checked, was made up and upon firing gave very similar results. Evidently some peculiar action, similar to the formation of a eutectic, occurs with $0.05 \mathrm{BaO}$.

These results indicate that an increase of $\mathrm{ZnO}$ at the expense of $\mathrm{BaO}$ gives colors tending toward blues and greens and away from purple tones. This contradicts Minton's statement ${ }^{1}$ in his discussion of my paper last year that "the effect of $\mathrm{BaO}$ produces blue green with $\mathrm{NiO}$ " and confirms my previous observations.

Series 2.-Glaze 1, crystalline blue, similar to glaze 5, series 1 , from which it differs only by $0.05 \mathrm{CaO}$ replacing $0.05 \mathrm{~K}_{2} \mathrm{O}$. The crystals are small but the effect is very pleasing; glaze 2, purplish blue of slightly mottled nature; glaze 3 , similar to glaze 2 ; glazes 4 and 5 , more of grey blue color. The increase of $\mathrm{CaO}$ at expense of the $\mathrm{K}_{2} \mathrm{O}$ seems to intensify the resulting blue color.

1.J. Am. Ceram. Soc., 1920, 669. 
High whiting and high zinc together gives light greyish blues. The surface of glaze 5 which contains only $\mathrm{CaO}$ and $\mathrm{ZnO}$ in the RO is of an unpleasant greasy nature.

Series 3.--Glaze 1, brown; glaze 2, purplish blue; glaze 3, purplish blue; glaze 4 , purple; glaze 5 , about like glaze 4 ; glaze 6 , reddish purple.

The results of this series confirm Pence's statement that purples and blues are developed as $\mathrm{ZnO}$ increases at the expense of $\mathrm{BaO}$ and $\mathrm{CaO}$. If we compare the results of this series with the results obtained in series 1 last year wherein $\mathrm{ZnO}$ was used to replace $\mathrm{BaO}$, we see that $\mathrm{BaO}$ and $\mathrm{CaO}$ produce much the same colors when used in connection with $\mathrm{ZnO}$.

Series 4.-Glazes 1 and 2, these glazes develop decided reds which have a more or less purplish tone; glaze 3 , light blue, similar to glaze 4 , series 2 ; glaze 4 , similar to glaze 3 ; glaze 5 , more reddish than glazes 3 and 4 .

In this series, with high $\mathrm{ZnO}$ and $\mathrm{BaO}$, the reddish tone frequently observed has developed into a red of a somewhat purplish tone. This red develops where the glaze is dipped rather heavy and seems to be a segregation on the surface of the blue. Where the glaze is dipped light, the blue color predominates with only here and there a fleck of red on the surface. This red color seems to be developed within the following narrow limits of RO composition:

$$
\begin{array}{rr}
0.15 & 0.20 \mathrm{~K}_{2} \mathrm{O} \\
.35 & .40 \mathrm{ZnO} \\
.45 & .40 \mathrm{BaO}
\end{array}
$$

Later experiments tend to confirm this action and indicate that a variation of only about 0.05 equivalent in any one of these three oxides is permissible.

Series 5.-Glaze 1, red; glaze 2, blue; glaze 3 , blue; glaze 4 , lighter blue; glaze 5 , lighter blue, nearer to turquoise.

The replacement of $\mathrm{BaO}$ with $\mathrm{MgO}$ in presence of $\mathrm{ZnO}$ gives blues, but lightens the tone. No purple blues are noticeable. The glazes are hardened somewhat as the $\mathrm{MgO}$ increases.

Series 6.-Glaze 1, blue; glaze 2, light grey blue; glaze 3 , faded lilac; glaze 4, more grey than glaze 3 . 
The $\mathrm{MgO}$ replacing $\mathrm{ZnO}$ in presence of $\mathrm{BaO}$ hardens the glaze more than in the previous series. Furthermore, greater changes in color occur. This is equivalent to saying that $\mathrm{ZnO}$ has a more powerful effect on the color produced by $\mathrm{NiO}$ than has $\mathrm{CaO}$ and $\mathrm{BaO}$.

Series 7.- Glaze 1, medium dark blue; glaze 2, bright glaze, yellow brown with blue segregations (Compare glaze 4, series 1); glaze 3 , light green semi-matt; glaze 4 , lighter in color than glaze 3 , semi-matt; glaze 5 , still lighter than glaze 4 .

In glaze 2 this series, with a content of $0.05 \mathrm{MgO}$, we observe the same phenomenon as in glaze 4 , series 1 , which contains $0.05 \mathrm{BaO}$. The glazes in this series are hardened when $\mathrm{MgO}$ replaces $\mathrm{CaO}$ and the colors are lightened and tend toward grey greens.

Series 8.-Glaze 1, light blue; glaze 2, mingled grey and blue; glaze 3 , good grey; glaze 4, grey, slightly browner than glaze 3.

In this series, wherein $\mathrm{MgO}$ replaces $\mathrm{ZnO}$ in presence of $\mathrm{CaO}$, nice greys are developed. Last year it was shown that greys were developed when $\mathrm{MgO}$ replaced $\mathrm{BaO}$ with no $\mathrm{ZnO}$ in the formula. This leads to the conclusion that greys are not developed when the $\mathrm{ZnO}$ is present in too large quantities and the tendency of $\mathrm{ZnO}$ is to produce greys of bluish tones.

Series 9.-All glazes of this series are reds of the same purplish tone as glazes 1 and 2 , series 4 . The reduction of $\mathrm{Al}_{2} \mathrm{O}_{3}$ does not destroy the red color. It does, however, soften the glaze and produces better surfaces.

Series 10.-The red color changes from purplish to brownish as the $\mathrm{NiO}$ is increased.

\section{Discussion of Results}

A study of these results brings out some interesting facts. In the first place, a very interesting red color has been produced using $\mathrm{NiO}$ as the coloring agent. This color seems to be confined to a very narrow range of glaze composition so far as the RO is concerned. A content of not less than $0.35 \mathrm{BaO}$ and $0.35 \mathrm{ZnO}$ seems necessary, but both must not be this low at the same time. 
This red color seems to be a crystalline segregation on the surface of a blue color, the blue always predominating when the glaze is dipped light. Within the limits studied the $\mathrm{Al}_{2} \mathrm{O}_{3}$ content may vary at will. The content of $\mathrm{NiO}$ influences the shades of red produced.

In the second place, more data on the development of grey colors is noted. It appears that $\mathrm{CaO}$ is necessary to the formula in producing greys; that the $\mathrm{ZnO}$ should not exceed 0.30 equivalent; that the $\mathrm{MgO}$ should approximate 0.15 equivalent; that $\mathrm{BaO}$ is not necessary in the formula, but that its presence is not detrimental. $\mathrm{BaO}$ may replace a part of the $\mathrm{CaO}$ as was shown in the paper of last year.

\section{Conclusions}

We conclude, therefore, that the following statements are justified as a result of this study:

(1) The dominant tendency of $\mathrm{ZnO}$ is to produce blue colors with $\mathrm{NiO}$, as already reported by Pence.

(2) $\mathrm{ZnO}$ is not necessary in the production of greys with $\mathrm{NiO}$ but may be present if it does not exceed 0.30 equivalent.

(3) $\mathrm{BaO}$ with $\mathrm{CaO}$ and $\mathrm{K}_{2} \mathrm{O}$ gives browns, with $\mathrm{ZnO}$, purples, reddish purples and reds when the proper proportions are used.

(4) $\mathrm{BaO}$ is not necessary to produce greys but may be present in the formula partly replacing $\mathrm{CaO}$.

(5) $\mathrm{CaO}$ with $\mathrm{ZnO}$ produces blues and must be present with $\mathrm{MgO}$ to produce greys.

(6) $\mathrm{MgO}$ tends to produce greyish tints when used with other oxides. To produce neutral greys it should be used with $\mathrm{CaO}$ or a combination of $\mathrm{CaO}$ and $\mathrm{BaO}$. Bluish tones of grey are obtained when $\mathrm{ZnO}$ is present.

(7) The coloring influence of $\mathrm{K}_{2} \mathrm{O}$ is slight but its presence promotes maturity and good surfaces.

Amprican Fncaustic Thing Company

ZaNesvil,Le, Ohio 